\title{
Ag-Bearing Mineralization of Nevenrekan Deposit (Magadan Region, Russia)
}

\author{
E. Podolian ${ }^{1,2(\bowtie)}$, I. Shelukhina ${ }^{1,2}$, and I. Kotova ${ }^{2}$ \\ 1 "RMRL" Ltd. (Raw Materials Researching Laboratory), \\ Saint Petersburg, Russia \\ podolyan@lims-lab.com \\ 2 Department of Mineral Deposits, Saint Petersburg State University, \\ Saint Petersburg, Russia
}

\begin{abstract}
Nevenrekan deposit, located in Magadan region, Russia, is a perspective Au-Ag deposit with average silver content $445 \mathrm{ppm}$ and gold $7.4 \mathrm{ppm}$. The study of the ores reveals the main Ag-bearing minerals: Au-Ag alloys, tetrahedrite-tennantite series and new phase $-\mathrm{Ag}_{8} \mathrm{SnSe}_{2} \mathrm{~S}_{4}$. New phase contains the main part of the silver of the deposit $-97.6 \%$.
\end{abstract}

Keywords: Silver $\cdot$ Ag-sulphosalts $\cdot$ Ag-bearing minerals $\cdot$ Epithermal $\cdot$ Argyrodite

\section{Introduction}

The Nevenrekan Au-Ag deposit is located in the Severo-Even district of the Magadan region, Russia. The site is located within the central part of the Okhotsk-Chukotka volcanogenic belt. The main structural element is cretaceous-paleogenic Nevenrekan intrusive dome, which is crossed by quartz-adularia and quartz-carbonate veins with hydrothermal origin. These veins contain ores with Au-Ag mineralization. This work is motivated by mineralogical criteria for understanding ore-forming processes which are essential for future efficient exploration.

\section{Methods and Approaches}

Methods of research include: (1) chemical analyses and its interpretation (include $\mathrm{X}$-Ray diffraction, atomic absorption analysis, inductively coupled plasma massspectrometry (ICP-MS) analysis for micro components and X-Ray fluorescence analysis for macrocomponents); (2) optical researches including petrographic research of thin sections and mineragraphic research of polish sections which are provided by electron microprobe analyses of chemical composition of ore minerals; (3) technological experiments (gravity и floatation methods of ores separation). 


\section{Results and Discussion}

The main types of rocks at the deposit are clastolaval rhyodacites and ignimbrite rhyodacites, which are host rocks, and quartz-adularia veins, which are gangue rocks. Ore mineralization of Nevenrekan deposit consists of 4 ore associations which are characterized by different temperature of formation: 1. rutile-kassiterite; 2. pyrite-arsenopyrite; 3. sphalerite-chalcopyrite-galena-Au-Ag alloys-stannite series- $\mathrm{Ag}_{8} \mathrm{SnSe}_{2} \mathrm{~S}_{4}$-tennantitetetrahedrite series with $\mathrm{Ag} ; 4$. hydrohematite. The most important paragenesis is the third one because it includes the main mineral concentrators of silver and gold. Technological and following chemical and mineralogical researches of beneficiaries demonstrate that the main concentrator of silver is sulphosalts, especially new phase $\mathrm{Ag}_{8} \mathrm{SnSe}_{2} \mathrm{~S}_{4}$, which contains $97.6 \%$ of all silver. According to crystallographic researches, phase $\mathrm{Ag}_{8} \mathrm{SnSe}_{2} \mathrm{~S}_{4}$ is orthorhombic and should belong to argyrodite group (Zhai et al. 2018). Nevenrekan deposit belongs to low-sulfidation type in classification of epithermal deposits (White and Hedenquist 1995).

\section{Conclusions}

The main Ag-bearing minerals at the Nevenrekan deposit are Au-Ag alloys, tennantitetetrahedrite series and $\mathrm{Ag}_{8} \mathrm{SnSe}_{2} \mathrm{~S}_{4}$ sulphosalt of argyrodite group, which contain $97.6 \%$ of silver. The mineral composition of ores and the mineral balance of silver determine the prospects of flotation flow sheet for ore beneficiation.

Acknowledgements. We thank Polymetal Engineering Company for the ore samples and RMRL Ltd. for sponsorship of the participation in $14^{\text {th }}$ International Congress for Applied Mineralogy.

\section{References}

Zhai D, Bindi L, Voudouris P, Liu J, Tombros S, Li K (2018) Discovery of Se-rich canfieldite, $\mathrm{Ag} 8 \mathrm{Sn}(\mathrm{S}, \mathrm{Se}) 6$, from the Shuangjianzishan $\mathrm{Ag}-\mathrm{Pb}-\mathrm{Zn}$ deposit, NE China: a multimethodic chemical and structural study. Miner Mag 1-21

White NC, Hedenquist JW (1995) Epithermal gold deposits styles, characteristics and exploration. SEG Newsl 23:9-13

Open Access This chapter is licensed under the terms of the Creative Commons Attribution 4.0 International License (http://creativecommons.org/licenses/by/4.0/), which permits use, sharing, adaptation, distribution and reproduction in any medium or format, as long as you give appropriate credit to the original author(s) and the source, provide a link to the Creative Commons license and indicate if changes were made.

The images or other third party material in this chapter are included in the chapter's Creative Commons license, unless indicated otherwise in a credit line to the material. If material is not included in the chapter's Creative Commons license and your intended use is not permitted by statutory regulation or exceeds the permitted use, you will need to obtain permission directly from the copyright holder.

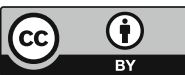

